\title{
Reliable entertainment: Spanish consumers' preferences regarding a film's country of origin
}

\author{
Ercilia García-Álvarez ${ }^{1}$, Nela Filimon ${ }^{2}$ and Jordi López-Sintas ${ }^{3 *}$ \\ ${ }^{1}$ Universitat Rovira $i$ Virgili, Tarragona, Spain \\ ${ }^{2}$ Universitat de Girona, Spain \\ ${ }^{3}$ Universitat Autonoma de Barcelona, Spain
}

- This article contributes to the study of cinema audiences in Europe by analyzing the actual behavior of Spanish moviegoers and their level of satisfaction. We modeled moviegoers' choice of film by country of origin (U.S.A., Spain, and other countries) according to a set of determinants: (1) consumers' interpretation of several sources of information, (2) motivations and (3) choice rules. We found three clear consumer stereotypes related to each type of film: (1) U.S.A. films were preferred by almost everyone (especially families and younger audiences); (2) Spanish films had audiences composed of middle-age and middle-class moviegoers; and (3) European productions were preferred by a social or intellectual elite. U.S.A. films dominate the Spanish market for the reason that they provide most of what moviegoers prefer, namely, familiar, reliable entertainment in Spanish; three characteristics that are not satisfied by Spanish and European films. Additionally, we discuss the implications for the European cultural policy.

Copyright $(2007$ John Wiley \& Sons, Ltd.

\section{Introduction}

Since 1980, U.S.A. films have constantly increased their presence and domination in the European market, shadowing the successful European productions from the 1950s and 1960s (Durand, 1958) and adversely affecting the European film industry trend according to recent facts. The European Audiovisual Observatory (EAO) reports that in 2001 - considered a successful year for the European cinema

\footnotetext{
*Correspondence to: Jordi López-Sintas, Universitat Autonoma de Barcelona, Facultat d'Economia i Empresa, Department d'Economia de l'Empresa, Edificio B, 08193-Bellaterra, Barcelona, Spain.

E-mail: Jordi.Lopez@uab.es
}

industry - U.S.A. films were seen by 600 million moviegoers whereas European film audiences totaled only around 200 million moviegoers in the country of origin and an additional 100 million moviegoers outside that country (Hieronymi, 2002). Spain follows a similar pattern, with U.S.A. films holding a dominant market share of $82 \%$ in 2000 , and Spanish films accounting only for $10 \%$ of the market (SGAE, 2000, p. 85).

European Union countries, in particular, are trying to reverse this market trend by devising industry policies that could foster their domestic film industry. For instance, in the period 2001-2005 (now extended to 2007) the EU MEDIA program has allocated a budget of 
EUR 400 million to promote European films outside their country of origin, European festivals and networks in the film industry, and pilot projects in digital television. Besides these financial and political efforts, members of the European Commission have insisted on the need to assess the real effectiveness of the present system in providing an answer to the unsolved problems of the European audiovisual market (Brunella, 2004). Based on this aim, a better understanding of European moviegoers' behaviors and preferences appears to be critical.

Nevertheless, research thus far has focused on understanding the U.S.A. film industry's competitive advantage (Hoskins et al., 1997), paying little attention to moviegoers' point of view. Many scholars have already pointed out the scarcity of studies on moviegoers (Austin, 1985; Meers, 2001), particularly in Europe, where this area remains underdeveloped (Vincendeau, 1998). In this vein, our article researches films' choices (from U.S.A., Spain, or other European and international films) of Spanish moviegoers and how they are associated to a set of determinants. Accordingly, after revising the literature, we modeled moviegoers' choice of film according to a set of sources of information, motivations and choice rules that enable us to understand moviegoers' preferences. Then we discuss our findings and, finally, we offer several implications for public and film industry policy in the European Union.

\section{Determinants of consumers' choice}

\section{An integrative view: hedonic and information processing perspectives of decision-making}

Movies are experiences consumed for pleasure rather than maximization of a material or tangible benefit. Recognizing this fact, Hirschman and Holbrook proposed a hedonic perspective of consumption (Hirschman and Holbrook, 1982; Holbrook and Hirschman, 1982) to analyze the aesthetic, intangible and subjective aspects of consumption products, especially aesthetic products like films. Defining the hedonic consumption as 'a primarily subjective state of consciousness with a variety of symbolic meanings, hedonic responses, and aesthetic criteria', Holbrook and Hirschman (Holbrook and Hirschman, 1982, p. 132) propose focusing on our interest in aesthetic products, like films, and the hedonic aspects of the consumption experience.

According to Hirschman and Holbrook (Hirschman and Holbrook, 1982, p.97), the hedonic perspective in no way advocates the reduction of research on the informationprocessing perspective (Howard and Sheth, 1967[1995]) of consumer decision-making, but nevertheless, it does argue for an increased attention to the symbolic aspects of consumption experience, also including the sociopsychological experiences that accompany product consumption (see also Durand, 1958, p. 285). The information-processing view of consumption is based on three elements: 1) a set of motives, 2) several courses of action (information), and 3) decision rules. Further it proposes that the way by which motives are matched with alternatives depends on decision rules, which in turn depend on the consumer's expertise (Howard and Sheth, 1967[1995]. p. 138). In keeping with this integrative view, we adopt a hedonic and informationprocessing perspective in this research.

\section{Classification of sources of information on the hedonic and tangible benefits of seeing a film}

There are several sources of information on films' probable capacity to provide a pleasurable experience, all needed to build an informed set of courses of action. Among them, critics and their reviews are considered a particularly important source of information in the entertainment industry, although it is not clear to what extent they are really capable of motivating moviegoers to attend movies. So, the question is: do consumers take experts' opinions into account when deciding which 
film to see? Ginsburgh and Weyers (Ginsburgh and Weyers, 1999, p. 278) pointed out in their study that judges in Cannes and Hollywood were not able to discriminate between goodquality movies and other movies. However, consumers and film critics seem to agree on film quality when the film comes out, although moviegoers are more consistent in their shortand long-run evaluations of films (p.276).

On the other hand, Eliashberg and Shugan (1997) have studied the consequences of critics on box-office revenues and showed that positive reviews have no impact on box office performance in the short-run (weeks 1-4 after release of the movie), but have a significant influence instead in the subsequent weeks (weeks 5-8) as well as on total revenues. These findings raise doubts about the role of critics as early motivators, but recognize the value of critical reviews as a forecasting tool for estimating the ultimate potential of a motion picture (p.268). Thus, according to these authors (p.270-271), critics should be considered predictors rather than influencers of consumers' choice.

There is limited evidence on whether the Academy Awards and movie genres have some impact on film box-office performance. Dodds and Holbrook (1988) evaluated the impact of the Academy Awards on film revenues and found significant effects by the best-picture, best-actor, and best-actress awards on post-award revenues. Smith and Smith (1986) found varying signs for the effects of different Academy Award types across different time periods, indicating that the relative importance of this explanatory variable can change over time. Later on, Prag and Casavant (1994) showed that the Academy Awards and the presence of major stars contributed significantly to revenues only when marketing expenditures were not included in the regressions, thus casting doubts on the role of experts who distribute the awards. In summary, the predictive power of these variables seems to be poor and unstable over time.

However, regardless of the evidence, the literature reviewed thus far does not reveal how moviegoers classify or interpret the various sources of information that reach their senses. Although the aggregate of social and cultural conditions that influence moviegoers to go to the movie theatre and see a film (what we will call a moviegoer's social environment) is usually classified as commercial (when coming from firm's marketing programs) or social stimulus (when coming from family members, friends and reference groups by word-of-mouth communication), it is not clear what specific sources of information moviegoers actually include in each class and how they affect a moviegoer's choice. In this vein, for example, moviegoers can interpret critics as being just another commercial tool of the film industry or as being a symbolic input forming part of their reference group.

\section{Moviegoers' motivation and choice rules}

Once moviegoers have interpreted the stimulus coming from their social environment, they have to check whether the promised pleasure is credible according to passed experiences and matches their motives as well. The decision-making process thus includes continuously updated information that classifies a particular film into a class of films (De Vany and Walls, 1999) and hence, capable of providing the benefits the moviegoer is seeking (Albert, 1998, p.252). So, starting from an equally interpreted stimulus we can expect that moviegoers differ in their choices according to their experience with films viewed and their interest in aesthetic products.

Choice rules may also differ in the sense that a moviegoer familiar with films has a regular evoked set of alternatives to satisfy his/her motives, but this is not the case of newcomers to the film industry (Howard and Sheth, 1967[1995]). Therefore, we can expect that the influence of the set of determinants analyzed may vary depending on experience. Accordingly, the experienced moviegoer also establishes mental rules for matching the 
alternatives with his motives and for rank-ordering them in terms of their wantsatisfying capacity. These choice rules are learned criteria and are summarized in the value that moviegoers assign to each type of film according to its country of origin.

\section{Research design}

\section{Research questions}

Following the review introduced in the previous section, our main purpose here was to: (1) discover the way Spanish moviegoers classify or interpret the different sources of information on the hedonic and material or tangible benefits of seeing a film; (2) measure how moviegoers' classification of sources of information plus a set of motivational indicators and choice rules determine the selection of a film's country of origin; and (3) identify the consumer profile for each type of film by country of origin.

\section{Sample}

Data were obtained from the 'Habits of Cultural Consumption' survey requested by the Sociedad General de Autores Españoles (SGAE) in 1998. The survey conducted home interviews of over 9000 individuals of either sex, 14 years of age or older, and living in Spain. The survey launched three quarter waves of about 3000 interviewees each, comprising a representative random sample, stratified by autonomous regions and municipalities according to size. Further technical characteristics are described in SGAE (2000).

\section{Determinants of film's choice}

Interviewees were asked how much they had been influenced by the set of indicators regarding the last film they had viewed. A list of sources of information about bedonic and tangible benefits was measured on a Likert scale with three values, from one to three (see the actual indicators in Table 2). However, motivators (interest in movies, interest in film broadcasting, interest in theatre broadcasting), choice rules (value of U.S.A. films, of Spanish films, and of films from other countries), and satisfaction (value of last film viewed) indicators were measured on a Likert scale, from one to six. Moviegoers were also questioned about the ticket paid, the type of movie theatre, and the country of origin of the last film viewed. The latter variable had three categories: U.S.A., Spain and other countries. This last category included films from Europe and third countries; however, films from countries outside Europe were exceptions. Finally, we constructed an indicator of expertise: those consumers going to the movies at least 2-3 or more times a month were classified as experts.

\section{Indicators of sociocultural categories}

In order to describe Spanish film consumers' profile, we selected a set of socioeconomic and cultural categories. Three main indicators (see Table 1) are considered in the specialized literature (Bourdieu, 1987) as a good approximation for the social class: socioeconomic status (SES), educational level (Education), and income level (Earnings). For the first case (SES), we worked with the Erikson-Goldthorpe procedure, EGP, (Erikson and Goldthorpe, 1992), as it is being used to analyze the relationship between social class and cultural consumption and is considered the most influential conceptualization and operationalization of social class in European sociology. We codified the SES indicator with seven categories, of which five are EGP categories: the first two are service categories (service 1) the highest socioeconomic category and service 2), and correspond to employees with a high position in the hierarchy of firms or government agencies; the third category stands for routine and non-manual workers (non-manual); the fourth includes employers and self-employed workers (entrepreneurs); and finally, the fifth category refers to skilled, semiskilled and unskilled employees with a labor contract (manual workers). Two additional SES categories were also included: 
Table 1. Descriptive statistics of socio-cultural categories

\begin{tabular}{|c|c|c|}
\hline Nominal variable & Levels (short and long labels, when needed) & $\%$ \\
\hline \multirow[t]{2}{*}{ Gender } & Male & 47 \\
\hline & Female & 53 \\
\hline \multirow[t]{5}{*}{ Age } & $<25$ & 22 \\
\hline & $25-34$ & 19 \\
\hline & $35-44$ & 16 \\
\hline & $45-54$ & 12 \\
\hline & $>54$ & 31 \\
\hline \multirow[t]{5}{*}{ Education } & Ed $1=$ Primary education or less & 15 \\
\hline & Ed2 = Low secondary (compulsory) & 50 \\
\hline & Ed3 $=$ High secondary & 22 \\
\hline & $\mathrm{Ed} 4=$ College & 7 \\
\hline & Ed5 = University degree & 6 \\
\hline \multirow[t]{5}{*}{ Social class (self-description) } & Low & 1 \\
\hline & MidLow $=$ Middle-Low & 6 \\
\hline & Middle & 24 \\
\hline & MidHigh $=$ Middle-High & 52 \\
\hline & High & 17 \\
\hline \multirow[t]{7}{*}{ SES } & $\mathrm{S} 1=$ Service 1 & 5 \\
\hline & $\mathrm{S} 2=$ Service 2 & 6 \\
\hline & NonM $=$ Non Manual & 7 \\
\hline & SMEsEnt $=$ Entrepreneurs of SMEs & 6 \\
\hline & Manual & 15 \\
\hline & NotinLabMar $=$ Not in labor market & 46 \\
\hline & Students & 15 \\
\hline \multirow[t]{4}{*}{ Marital status } & Single & 35 \\
\hline & Married & 54 \\
\hline & Widowed & 8 \\
\hline & Divorced & 3 \\
\hline \multirow[t]{5}{*}{ Earnings } & Ea1 $=<€ 600$ a month & 19 \\
\hline & $\mathrm{Ea} 2=€ 600-900$ a month & 30 \\
\hline & $\mathrm{Ea} 3=€ 900-1200$ a month & 30 \\
\hline & $\mathrm{Ea} 4=€ 1200-1800$ a month & 16 \\
\hline & Ea5 $=>€ 1800$ a month & 5 \\
\hline \multirow[t]{4}{*}{ Size of municipality } & $\mathrm{H} 1=<100,000$ inhabitants & 36 \\
\hline & $\mathrm{H} 2=100,000-200,000$ inhabitants & 11 \\
\hline & $\mathrm{H} 3=$ Metropolitan areas & 15 \\
\hline & $\mathrm{H} 4=$ Metropolitan areas and provincial capital & 38 \\
\hline \multirow{2}{*}{ Children under age 14 living at home } & None & 71 \\
\hline & Yes & 29 \\
\hline \multirow[t]{2}{*}{ People of age 14 or above living at home } & Two or - & 50 \\
\hline & Two+ & 50 \\
\hline
\end{tabular}

one for people not in the labor force (housewives, retired people, and other subjects not assigned to any other category) ${ }^{1}$ and a last category for students. The rest of the indicators are explained in the same table. The case of

\footnotetext{
${ }^{1}$ As can be seen in Table 1, this category accounts for $46 \%$ of the sample, a figure that is apparently too high, but nevertheless representative of the Spanish population if we consider that unemployed individuals accounted for $18.8 \%$ of the population in 1998 (see INE, 1999, p. 350).
}

earnings, though, merits some discussion; even though our sample of monthly earnings above EUR 1800 accounts for 5\% only, the population figures for 1997 and 1999 were 16.5\% and 20.2\% respectively for household monthly earnings in the range EUR [1587-2380] (INE, 2001, p. 382, and INE, 2003, p. 328). These discrepancies suggest that many respondents may have understated their earnings, although the data are not perfectly comparable given 
Table 2. Rotated factor loadings. (Loadings greater than 0.4 are underlined)

\begin{tabular}{|c|c|c|c|c|c|c|}
\hline & Factor 1 & Factor 2 & Factor 3 & Factor 4 & Factor 5 & Factor 6 \\
\hline & $\begin{array}{c}\text { Social } \\
\text { information }\end{array}$ & $\begin{array}{l}\text { Comfort and } \\
\text { convenience }\end{array}$ & $\begin{array}{l}\text { Film } \\
\text { characteristics }\end{array}$ & $\begin{array}{l}\text { Commercial } \\
\text { information }\end{array}$ & Plot & $\begin{array}{l}\text { Original } \\
\text { version }\end{array}$ \\
\hline $\begin{array}{l}\text { Word-of-mouth } \\
\text { (I have heard a lot about it) }\end{array}$ & $\underline{0.794}$ & 0.121 & 0.007 & -0.118 & 0.101 & 0.006 \\
\hline Actors & 0.202 & 0.009 & 0.757 & -0.004 & 0.217 & -0.006 \\
\hline Director & 0.004 & 0.115 & $\overline{0.801}$ & 0.202 & -0.008 & 0.146 \\
\hline Plot & 0.134 & 0.107 & $\overline{0.102}$ & 0.101 & 0.897 & 0.006 \\
\hline Advertisements & $\underline{0.423}$ & 0.180 & -0.001 & $\underline{0.551}$ & $\overline{0.008}$ & -0.131 \\
\hline Academy awards & $\overline{0.008}$ & 0.008 & 0.133 & $\overline{0.836}$ & 0.007 & 0.108 \\
\hline Original version & 0.006 & 0.006 & 0.007 & $\overline{0.004}$ & 0.005 & 0.964 \\
\hline Film dubbed into Spanish & 0.002 & 0.665 & 0.002 & 0.007 & 0.423 & $-\overline{0.008}$ \\
\hline Pleasant movie theatre & 0.008 & $\overline{0.764}$ & 0.149 & 0.162 & $\overline{0.006}$ & 0.005 \\
\hline Movie theatre near home & 0.240 & $\overline{0.764}$ & 0.007 & 0.001 & -0.007 & 0.008 \\
\hline Famous film & 0.721 & $\overline{0.172}$ & 0.004 & 0.291 & 0.007 & -0.005 \\
\hline Good reviews & 0.632 & 0.004 & 0.245 & 0.291 & 0.002 & 0.101 \\
\hline
\end{tabular}

that our sample collected data about individuals not households. This is actually one limitation of the data set we worked with.

\section{Analysis}

Classification of sources of information about bedonic and tangible benefits of seeing a film

Exploratory factor analysis was used to classify the set of indicators about sources of information. Our hypothesis was that the set of indicators we observed $\left(z_{i}\right)$ could be described as a function of a small number of underlying common factors $\left(F_{k}\right)$ and a set of specific factors $\left(d_{i}\right)$, as indicated in the equation below:

$$
z_{i}=a_{i 1} F_{1}+\ldots+a_{i k} F_{k}+d_{i}
$$

The $k$ factors will help us to understand how consumers classify the sources of information about hedonic and tangible benefits. Later, both types of consumers' factor scores were used in the choice model (see Roberts, 1984, for a similar application).

\section{Choice model}

We modeled the deterministic consumer's benefit derived from choice of $m$ film's country of origin for individual $i, \mu_{i m}$, by using an additive utility function. Thus,

$$
\mu_{i m}=\sum_{p} x_{i p} \beta_{m p}=\mathbf{x}_{i} \beta_{m}
$$

where $x_{i p}$ is the amount of attribute $p$ possessed by $m$ film's country of origin according to moviegoer $i$, and $\beta_{m p}$ are the estimated utility function coefficients for the $m$ film's country of origin and attribute $p$. Finally, we decided to model the uncertainty in consumer's benefit of choosing the film's country of origin by using a stochastic additive component, $\varepsilon_{i m}$, that is identically and independently distributed according to the double exponential distribution. Thus, the random utility model is

$$
u_{i m}=\mu_{i m}+\varepsilon_{i m}
$$

and the probability of choosing film type $m$ is given by the following multinomial logit model: ${ }^{2}$

$$
\operatorname{Pr}\left(y_{i}=m \mid \mathbf{x}_{i}\right)=\frac{\exp \left(\mathbf{x}_{i} \beta_{m}\right)}{\sum_{p} \exp \left(\mathbf{x}_{i} \beta_{p}\right)}
$$

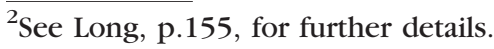


Table 3. Results of the multinomial choice model. (Films from other countries is the category of reference)

\begin{tabular}{|c|c|c|c|c|c|c|}
\hline & \multicolumn{3}{|c|}{ Country of origin: U.S.A. } & \multicolumn{3}{|c|}{ Country of origin: Spain } \\
\hline & Coefficient & $\begin{array}{c}p \text {-value } \\
\text { Wald test }\end{array}$ & $\operatorname{Exp}(\operatorname{coef})$ & Coefficient & $\begin{array}{l}p \text {-value } \\
\text { Wald test }\end{array}$ & $\operatorname{Exp}($ coef $)$ \\
\hline Y-intercept & 6.42 & 0.00 & & 4.24 & 0.01 & \\
\hline Value of U.S.A. films & 0.49 & 0.00 & 1.63 & 0.09 & 0.46 & 1.09 \\
\hline Value of Spanish films & -0.01 & 0.92 & 1.01 & 0.35 & 0.02 & 1.42 \\
\hline Value of European films & -0.59 & 0.00 & 0.56 & -0.48 & 0.00 & 0.62 \\
\hline Interested in movies & -0.41 & 0.03 & 0.66 & -0.49 & 0.02 & 0.61 \\
\hline Interested in film broadcasting & 0.07 & 0.74 & 1.07 & 0.16 & 0.47 & 1.17 \\
\hline Interested in theatre broadcasting & -0.23 & 0.20 & 0.79 & -0.28 & 0.16 & 0.76 \\
\hline Expert $=$ Yes & -0.26 & 0.35 & 0.77 & -0.01 & 0.96 & 0.99 \\
\hline Social information & 0.70 & 0.00 & 2.02 & 0.73 & 0.00 & 2.07 \\
\hline Comfort and convenience & 0.31 & 0.05 & 1.37 & 0.08 & 0.64 & 1.08 \\
\hline Film characteristics & 0.03 & 0.81 & 1.04 & 0.43 & 0.01 & 1.53 \\
\hline Commercial information & 0.42 & 0.03 & 1.52 & 0.28 & 0.17 & 1.33 \\
\hline Plot & 0.15 & 0.25 & 1.16 & -0.11 & 0.44 & 0.90 \\
\hline Original version & -0.26 & 0.00 & 0.77 & 0.14 & 0.20 & 1.15 \\
\hline
\end{tabular}

\section{Results}

How moviegoers interpret the set of sources of information on the hedonic and tangible benefits of seeing a film

We factor-analyzed the $12 \times 12$ correlation matrix using the principal components procedure and varimax rotation (Barlett's test rejected the null hypothesis of sphericity: $\chi^{2}=4108.64 ; \quad d f=66 ; \quad p$-value $\left.<0.0001\right)$. A six-factor solution resulted, based on the following criteria: 1) a significant drop in the Scree plot following the sixth factor; 2) the first six factors were the most meaningful, rich, and interpretable, loading each indicator high in only one factor; 3) the six-factor solution explained a high proportion of the indicators' variance $(69 \%)$; 4) subsequent confirmatory factor analysis suggested that six factors were enough to reproduce the indicators' correlation matrix $\left(\chi^{2}=6.65 ; d f=9 ; p\right.$-value $<$ $0.674)$.

The varimax rotation suggested the following factor interpretations (see Table 3): Factor 1, named social information; Factor 2, comfort and convenience; Factor 3, film characteristics; Factor 4, commercial information; Factor 5, film plot; and Factor 6, original version. With no exception, the six-factor solution accounted for more than $40 \%$ of the variation of each of the 12 indicators. ${ }^{3}$

\section{Determinants of choice}

Film choice was modeled according to the six factors found plus the motivational factors (moviegoers' interest in films in general, interest in watching TV films or TV theatrical performances), and the choice rules (moviegoers' value of films from the U.S.A., Spain or other European and foreign countries). Finally, we also included an indicator of the moviegoer's expertise (if $s /$ he goes to the movie theatre at least 2-3 or more times a month).

The likelihood ratio test suggests that all variables have an effect on dependent categories, but moviegoers' interest in watching TV films or theatrical performances and moviegoers' expertise are only marginally meaningful (model residual deviance 1917.806, and AIC 1973.806). Furthermore, the reduced model predicts almost as well as the one with the original variables. As Howard and Sheth (1967[1995]) suggested that the

\footnotetext{
${ }^{3}$ Version 11.5 of the SPSS statistical program was used to estimate model parameters and factor scores.
} 
choice model could differ between expert and inexpert moviegoers, we estimated a model with an interaction between expertise and moviegoers' value of the country of origin film. The AIC statistic was 1979.542 , greater than the one for the reduced model. In summary, the statistics suggest that the simplified model explains the moviegoers' choice of the country of origin film better. ${ }^{4}$

In order to give a comprehensive interpretation of the results, we added one column labeled exp(coef) representing the exponential of the model's coefficients (see Long, 1997). For an actual change $\delta$ in a variable, the odds of outcome $m$ versus outcome $n$ (the category of reference) are expected to change by a factor of $\exp \left(B_{k, m \mid n} \delta\right)$, holding all other variables constant. Thus, the factor of change for a unit change in the variable value of U.S.A. films is 1.63 relative to other country of origin films, i.e., the odds of choosing a U.S.A. film will increase $63 \%$ relative to other country of origin films, and $49 \%$ relative to the Spanish ones $(\exp (0.49-0.09)=1.49)$.

To complete the picture, the behavioral analysis of the satisfaction level achieved through viewing any type of film was analyzed, and no differences were found (an ANOVA gave the following results: F-value $=0.439$, $d f=2, p$-value $=0.644$, for means between 4.55 and 4.66). Each type of moviegoer received what $\mathrm{s} /$ he expected.

\section{Sociocultural categories associated to moviegoers}

Moviegoers' differences according to the usual descriptors are not large but there are differences. Instead of showing a table with column profiles, we decided to plot them using a triangle plot, as there were only three dependent categories (see Greenacre and Hastie, 1987). However, since the profiles were not very different, they were plotted too close together to allow an easy interpretation.

\footnotetext{
${ }^{4}$ This analysis used the multinomial function of the $\mathrm{R}$ language and environment for statistical computing $(R$ Development Core Team, 2004, version 1.9.0.).
}

For that reason we decided to obtain the symmetrical plot of a correspondence analysis. $^{5}$

The top left plot in Figure 1 shows the association between consumer's gender, age, education and film's country of origin; the top right plot, consumer's self-description of social class, EGP socioeconomic status classification, family's monthly earnings and film's country of origin; the bottom left plot shows marital status, size of municipality, whether the consumer has any children under age 14, and whether there are more than two people above age 14 living at home; finally, the bottom right plot shows the type of movie theatre that consumers attend and whether they paid full price for the ticket. To interpret Figure 1 we only have to remember that the axes cross each other at the sample mean profile, so that the right (left) side shows categories with positive (negative) differences. The same criteria apply for the vertical axis. For instance, American films seem to have a profile similar to the sample mean (it is near to the origin), but films from other European and international countries are placed to the left, as they have a profile of moviegoers that differ from the sample mean.

\section{Discussion}

In order to study Spanish consumers' film choice by country of origin, we first analyzed how a set of sources of information on hedonic and material benefits were interpreted and classified by moviegoers, and how they had influenced moviegoers' choice of film. Thus, according to our results, Spaniards interpret the Academy Awards and film advertisements as commercial information (Factor 4), lending support to the findings of Ginsburgh and Weyers (1999) and Prag and Casavant (1994) that Academy Awards and marketing expenditures are associated. Moviegoers influenced

${ }^{5}$ study used the correspondence analysis function of ADE-4 package version 1.1-2 (see Thioulouse et al., 1997) implemented on the R language and environment for statistical computing (R Development Core Team, 2004, version 1.9.0). 


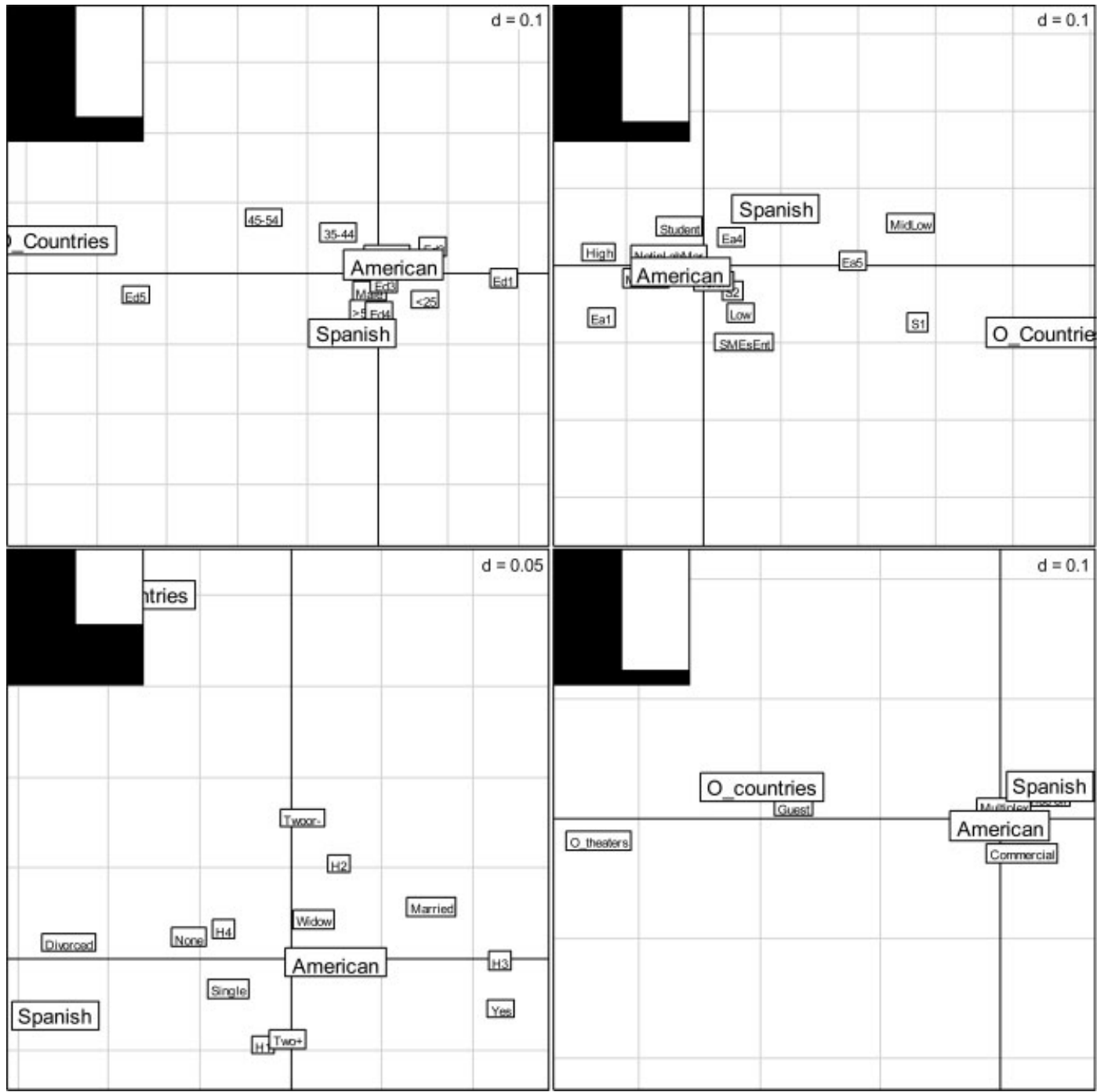

Figure 1. Correspondence analysis symmetrical plots of cultural indicators and country of origin film.

by advertisements were also influenced by the Academy Awards, and Academy judges were probably also influenced by marketing expenditures, as suggested by Prag and Casavant (1994).

On the other hand, film reviews were seen as part of the moviegoers' social environment, not commercial (good reviews were associated with famous films and word-of-mouth in Factor 1). This fact is in line with 1) Eliashberg and Shugan's (Eliashberg and Shugan, 1997) suggestion that critics are not early motivators of consumers to see a film, but rather a forecasting tool, and 2) also in line with Durand's (Durand, 1958) proposition that commercial information does not persuade moviegoers to attend films they really do not want to see (the impact of commercial information is smaller than the impact of social information, in all cases). The sociological explanation tells us that critics and their readers are linked through a certain kind of identity, functioning as a reference group. So, readers of newspapers fall into the typical reader position assumed by the critic role (Giles and Middleton, 1999, p.231) explaining the forecasting tool interpretation, instead of the alternative critics' motivatorrole. Contrary to Burzynski and Bayer's (Burzynski and Bayer, 1977) expectations, word-of-mouth does not oppose the critics, 
but both configure the social information factor that opposes the advertisements and Academy Awards.

Three competing factors about hedonic benefits were related to the consumer's film choice: film characteristics (Factor 3), plot (Factor 5) and original version (Factor 6). Wellknown actors, actresses and directors all influenced consumers and had a high impact on choosing a Spanish film, but not an American one. The other two factors, plot and original version, correlate only with the variable of the same name (see Table 2) and had a small impact on choice, not statistically significant for the plot, but significant for the original version, negatively affecting American films. Finally, one factor that is both material and tangible, namely comfort and convenience (Factor 2), is correlated with films dubbed into Spanish, a pleasant movie theatre and a movie theatre near home; the comfort and convenience factor positively affected the choice of American films.

Concerning moviegoers' motivations and choice rules, our findings suggest that the perceived value of U.S.A. films, as a choice rule, is as consistent as the value of Spanish ones (positively affect their own probability of choice, but not the others as seen in Table 3), but not as much as the value of European films (moviegoers who value European films are less likely to choose Americans or Spanish). In spite of the value of U.S.A. and Spanish films and of their high estimated mean, the value of European films had the greatest impact on the probability of choosing a film. Contrary to the findings of Fernández-Blanco et al. (2002), however, moviegoers who hold Spanish films in great esteem apparently do not have a lower probability of choosing a U.S.A. film, but the impact is simply null. On the other hand, motivating factors (interest in movies, film broadcasting, and theatre) seem to reduce the probability of choosing either an American or a Spanish film compared to films from other countries, except for those consumers interested in broadcast films.

To sum it up, we found three clear types of moviegoers related to each type of film (see also casual facts reported by Kerrigan and
Özbilgin, 2004). Thus, moviegoers of U.S.A. films appear to be consumers of mass culture, since commercial information (advertisements and Academy Awards) has a much greater positive impact on U.S.A. film consumers than on patrons of films made in other countries, although not as high as the impact of social information. Moviegoers of U.S.A. films value comfort and pleasure above intellectual gratification (enjoying films in their original version requires a high propensity to read subtitles, if you do not know foreign languages, which does not seem to be sufficiently intellectually gratifying), and actors and directors do not have a meaningful impact in discriminating among moviegoers of U.S.A. films and those choosing films from other countries except for Spanish films (the value of U.S.A. films seem to be the choice rule rather than the film's characteristics (actors and director). This group of consumers is the largest, although its frequency of attendance is the lowest, with a pattern of consumption consistent with a demographic profile resembling the average profile of the Spanish society, namely a variety of ages and educational levels.

Spanish films' moviegoers, on the contrary, were less influenced by commercial information and a bit more by social information (word-of-mouth and good reviews). Furthermore, they value Spanish films more than films from the U.S.A. and other countries and, accordingly, were influenced by the film's characteristics (one expects a great variation in quality among Spanish films in comparison to the U.S.A. films and better domestic knowledge), but comfort and convenience do not affect the choice as in the case of U.S.A. films. This segment exhibits a higher frequency of attendance than the moviegoers seeing U.S.A. films. Despite these differences between consumers of U.S.A. and Spanish films, the demographic profile is quite similar, although with moviegoers of Spanish films being slightly older, more educated and wealthier and including more unmarried and divorced individuals than the U.S.A. film segment.

Finally, moviegoers of European films seem to be the most cosmopolitan: they prefer films 
in their original version (they speak and read several languages), are interested in movies and theatre in general, and place a low value on U.S.A. and Spanish films. They are heavy consumers not influenced by information (social or commercial), film characteristics, or the comfort and convenience of the movie theatre. In short, these filmgoers are motivated to make an effort to see a film.

\section{Conclusions and implications}

Our research aim was to gain a better understanding of Spanish moviegoers. We found that viewers of each type of film, either U.S.A., Spanish or from other European countries were different. It seems that consumers were more interested in what they were familiar with, in what is closer, and in what most resembles the films they were used to. This conclusion is supported by the fact that results indicated (1) a clear preference for films dubbed in Spanish, which is the case for the U.S.A. films that are even dubbed into other local languages (moviegoers feel familiar with the language), (2) a more cultural closeness with the American style of life than with other European styles of life, and (3) a long-term habit of watching U.S.A. films, grounded by a U.S.A. film industry which has dominated the European market for many years. Paradoxically, even though the European Union has been making an effort to build a single European film market, the results indicate that most Spanish moviegoers are more familiar with and feel closer to U.S.A. films than to the European ones.

Based on moviegoers' preferences and sociocultural indicators, U.S.A. films are better known, and a more reliable type of film (the value of U.S.A. films was statistically more meaningful) when it comes to entertainment targeting the mass market (mainly families and young people). Spanish films, however, seems to be less reliable (too much variability in their entertainment value) and target mainly the middle social classes, whereas other European films were entertaining only if the consumer had the necessary resources - time, linguistic abilities, etc. - making them films that apparently address a social elite. The first two segments seem to match the so-called type of 'movie-theatre goers' and the latter, the 'moviegoers' group proposed by Durand (1958).

The results of the Spanish consumers' choice model reveal that the language of the film is determinant. At present, however, films from countries other than the U.S.A. and Spain are normally not dubbed but shown in original version with subtitles. Consequently, the audience is small and highly cultivated (social and cultural indicators reveal they are part of the social/intellectual elite). As a result, European films are not able to reach the majority of Spanish moviegoers, making it difficult to promote cultural diversity among European countries and weakening the European film industry's competitive position versus the U.S.A.. It follows that if U.S.A. films are dubbed in order to compete, then European films should also be dubbed. This finding leads to political implications; for instance, Spanish regional governments investing funds to dub foreign films as a device to foster the use of the local language (e.g., Catalan and Basque governments do pay for dubbing) should actually prioritize the dubbing of European films instead of American ones. In the same line, European public television, in keeping with the goal of making European films (and other audiovisual productions) closer and more familiar to the majority of moviegoers, should also increase the broadcasting of dubbed European films.

\section{Acknowledgements}

The authors would especially like to express their appreciation to Carles Padrós-Reig for his insightful comments on an earlier draft and to SGAE for providing access to their database. Anonymous reviewers and participants in the 1st Joint Workshop of the Nonprofit and Arts/ Heritage Marketing Special Interest Groups of the Academy of Marketing, London, 15th March 2006, are also acknowledged for their helpful 
comments on an earlier version of this manuscript. This research was funded by Grant \# BEC2003-04462 of the Spanish Ministry of Education and Science and by research funds from FEDER and Centre for Studies and Research in Humanitities at UAB.

\section{Biographical notes}

Ercilia García Álvarez is Associate Professor at the Department of Management, Universitat Rovira i Virgili, Tarragona. Her research interest concerns the production and consumption of culture, and presently she is an Associate Researcher at the Centre for Studies and Research in Humanities at Universitat Autònoma de Barcelona (UAB)

Nela Filimon is Lecturer at the Department of Economics, Universitat de Girona. Currently she is conducting research on the economics of entertainment at the Centre for Studies and Research in Humanities at UAB (antalya. uab.es/cehum/).

Jordi López Sintas is Associate Professor at the Department of Business Economics, UAB, and Managing Director of the Centre for Studies and Research in Humanities at UAB. Currently his main research interest is the analysis of the production and consumption of culture from an interdisciplinary approach.

\section{References}

Albert S. 1998. Movie stars and the distribution of financially successful films in the motion picture industry. Journal of Cultural Economics 22: 249-270.

Austin BA. 1985. Current Research in Film: Audiences, Economics, and Law, Austin BA (ed.). Ablex Publishing Corporation: Norwood, NJ.

Bourdieu P. 1987. What makes a social class? On the theoretical and practical existence of groups. Berkeley Journal of Sociology 23: 1-17.

Brunella E. 2004. Bigger Europe: opportunities of the cinema-interview with Ms Viviane Reding. European Cinema Journal 6: 1-2.

Burzynski MH, Bayer DJ. 1977. The effect of positive and negative prior information on motion picture appreciation. Journal of Social Psychology 101: 215-218.

De Vany A, Walls WD. 1999. Uncertainty in the movie industry: does star power reduce the terror of the box office? Journal of Cultural Economics 23: 285-318.

Dodds J, Holbrook MB. 1988. What's an Oscar worth? An empirical estimation of the effects of nominations and awards on movie distribution and revenues. In Current Research in Film: Audience, Economics, and Law (vol 4), Austin BA (ed.). Ablex Publishing Corporation: Norwood, NJ; 72-88.

Durand J. 1958. Le Cinéma et son Public. Editions Sirey: Paris.

Eliashberg J, Shugan SM. 1997. Film critics: influencers or predictors? Journal of Marketing 61(2): $68-78$.

Erikson R, Goldthorpe JH. 1992. The Constant Flux: A Study of Class Mobility in Industrial Societies. Calendon Press: Oxford.

Fernández-Blanco V, Prieto-Rodríguez J, MuñizArtime C, Gutiérrez del Castillo R. 2002. Cinéfilos, Videoadictos y Telespectadores. Fundación Autor: Madrid.

Giles J, Middleton T. 1999. Studying Culture: A Practical Introduction. Blackwell: Oxford.

Ginsburgh V, Weyers S. 1999. On the perceived quality of movies. Journal of Cultural Economics 23: 269-283.

Greenacre M, Hastie T. 1987. The geometric interpretation of correspondence analysis. Journal of the American Statistical Association 82(398): 437-447.

Hieronymi R. 2002. The circulation of European films: first improvements and much to be done. European Cinema Journal 6(4): 4.

Hirschman EC, Holbrook MB. 1982. Hedonic consumption: emerging concepts, methods and propositions. Journal of Marketing 46: 92-101.

Holbrook MB, Hirschman EC. 1982. The experiential aspects of consumption: consumer fantasies, feelings, and fun. Journal of Consumer Research 9: $132-140$.

Hoskins C, McFadyen S, Finn A, Jackel A. 1997. Evidence on the performance of Canada/Europe co-production in television and film. Journal of Cultural Economics 21: 129-138.

Howard JA, Sheth JN. 1967[1995]. A theory of buyer behavior. In Marketing Classics, Enis 
BM, Cox KK, Mokwa MP (eds). Prentice Hall: Englewood Cliffs, NJ; 137-155.

INE. 1999. Anuario Estadístico de España. Instituto Nacional de Estadística: Madrid.

INE. 2001. Anuario Estadístico de España. Instituto Nacional de Estadística: Madrid.

INE. 2003. Anuario Estadístico de España 2002/ O3. Instituto Nacional de Estadística: Madrid.

Kerrigan F, Özbilgin M. 2004. Film marketing in Europe: bridging the gap between policy and practice. International Journal of Nonprofit and Voluntary Marketing 9(3): 229-237.

Long JS. 1997. Regression Models for Categorical and Limited Dependent Variables. SAGE: Thousand Oaks, CA.

Meers P. 2001. Is there an audience in the house?Film audiences-Critical essay. Journal of Popular Film and Television Fall: 1-10.

Prag J, Casavant J. 1994. An empirical study of the determinants of revenues and marketing expenditures in the motion picture industry. Journal of Cultural Economics 18(3): 217-235.
R Development Core Team. 2004. R: A Language and Environment for Statistical Computing. R Foundation for Statistical Computing: Vienna, Austria.

Roberts JH. 1984. A multiattribute utility diffusion model: Theory and application to the pre-launch forecasting of automobiles. Ph.D. dissertation. MIT Sloan School of Management: Cambridge, Massachusetts.

SGAE. 2000. Informe SGAE sobre Hábitos de Consumo Cultural. Sociedad General de Autores Españoles. Fundación Autor: Madrid.

Smith SP, Smith VK. 1986. Successful movies: a preliminary empirical analysis. Applied Economics 18(5): 501-507.

Thioulouse J, Chessel D, Dolédec S, Olivier JM. 1997. ADE-4: a multivariate analysis and graphical display software. Statistics and Computing 7(1): 75-83. DOI: 10.1023.

Vincendeau G. 1998. Issues in European cinema. In The Oxford Guide to Film Studies, Hill J, Chusch Gibson P (eds). (chapter 6). Oxford University Press: Oxford. 